\title{
Production of embryos by oocyte cytoplast-blastomere fusion in domestic animals
}

\author{
N. L. First and R. S. Prather* \\ Department of Meat and Animal Science, University of Wisconsin, Madison, WI 53706, USA; and \\ *Department of Animal Sciences, University of Missouri, Columbia, MO 65211, USA
}

\begin{abstract}
Summary. Embryos of amphibians, sheep, cattle, pigs and rabbits have been multiplied by nuclear transfer. Successful nuclear transfer in these species has been accomplished by transfer of a blastomere from a late-stage embryo into an enucleated oocyte with large scale multiplication by repeating the procedure using blastomeres from the embryos produced from nuclear transfer. This allows the production of clonal lines which, when appropriately selected for performance in a given trait, can be reproduced to capture in the offspring expression of additive and non-additive inheritance.

The efficiency of these procedures is high only for amphibian embryos for which as many as 1000 offspring can be made from a blastula- to gastrula-stage embryo and the process repeated 60-100 times with descendant embryos. In domestic animals the largest number of offspring from one embryo has been 8 calves. Embryos as late as the 64-cell stage in cattle and 120-cell blastocyst in sheep have been used successfully as donors of blastomeres. Recloning has also been done in cattle. Nuclear transfer potentially provides a mechanism for multiplication and production testing of clonal lines, a method for rapid genetic improvement and rapid propagation of a selected genotype. Unfortunately the present efficiencies of subsequent embryo development, pregnancy and embryo survival are less than normal. This paper reviews variables contributing to reduced efficiency and research to improve nuclear transfer.
\end{abstract}

Keywords; nuclear transfer; embryo cloning

\section{Introduction}

Nuclear transfer is being developed in cattle, sheep and pigs as a method for clonal multiplication of genetically valuable embryos. It is usually accomplished by transfer of a blastomere from a late stage embryo into an enucleated oocyte, followed by large scale multiplication by repeating the procedure using blastomeres from the embryos produced from nuclear transfer (Fig. 1). This allows the production of clonal lines which, when appropriately selected for performance in a given trait, can be reproduced to capture in the offspring expression of both additive and non-additive inheritance.

Historically nuclear transfer was first used (Briggs \& King, 1952) to show that nuclei of blastocyst-stage amphibian embryos, a differentiated state, when transferred into enucleated eggs could be reprogrammed to direct early embryo development again and could result in the production of live young (Fischberg et al., 1958; McKinnell, 1962). Subsequently it was shown that success in amphibians resulted if the donor nuclei were obtained before gastrulation whereas nuclei from differentiated tissues were seldom reprogrammed for re-expression and term development (Gurdon, 1986). 
In mammals, nuclear transfer by direct microinjection of mouse blastocyst inner cell mass or trophoblast into enucleated pronuclear mouse zygotes was performed by Illmensee \& Hoppe (1981). Three mice were born from inner cell mass tissue whereas differentiated trophoblast cells produced neither blastocysts nor live offspring. A more efficient system for introducing nuclei by use of cell fusion was developed by McGrath \& Solter (1983). Using cell fusion these authors and others (McGrath \& Solter, 1984; Robl et al., 1986) could not repeat the results of Illmensee \& Hoppe (1981). So far, the only nuclear transfers in rodents resulting in pregnancies or live birth have been transfers between close embryonic stages such as 4 - and 8-cell blastomeres into enucleated 2-cell embryos (Robl et al., 1986; Tsunoda et al., 1987). In domestic species offspring have resulted from fusion of late stage blastomeres into enucleated oocytes in sheep (Willadsen, 1986; Smith \& Wilmut, 1989), cattle (Prather et al., 1987; Bondioli et al., 1990), pigs (Prather et al., 1989a) and rabbits (Stice \& Robl, 1989).

Failures in the mouse may relate to the early transition of the genome of the mouse embryo from maternal to embryonic control of development relative to the other species. This transition occurs at the 3000-4000 cell stage in amphibians (Nakakura et al., 1987), but at the 1-2cell stage in the mouse (Flach et al., 1982), 4-cell stage in pigs (Tomanek et al, 1989) and the 8-16-cell stage in sheep (Crosby et al. 1988) and cattle (Barnes, 1988; Barnes \& Eyestone, 1990).

For cattle, at least four companies are attempting to develop cloning procedures to an efficiency sufficient to allow mass production of cloned embryos and one company is already marketing embryos resulting from nuclear transfer. However, the frequency of developed blastocysts and maintained pregnancies after nuclear transfer has been less than normal with approximately one quarter of the nuclear transfers resulting in blastocysts and about one quarter of the blastocysts transferred into recipients resulting in maintained pregnancies (Prather et al., 1987; Stice \& Robl, 1989; Bondioli et al., 1990; Smith \& Wilmut, 1990).

Variables influencing the efficiency of nuclear transfer include the efficiency of oocyte enucleation, the developmental competence of the recipient oocyte and oocyte age at nuclear transfer, the efficiency of fusion of the blastomere into an enucleated oocyte and the efficiency of oocyte activation by the fusion process. Also important may be cell cycle synchrony of blastomere and oocyte at fusion. These variables are being studied and high efficiency in each of the required steps is being rapidly achieved (Bondioli et al., 1990; Prather \& First, 1990b; Smith \& Wilmut, 1990).

The number of clones produced depends on the number of identical donor cells or blastomeres from one donor embryo and on the number of generations of recloning performed. The latest nuclear donor cell stages used successfully have been the 3000-4000-cell blastula and gastrula stages in amphibians (Gurdon, 1986), the 8-cell stage in pigs (Robl \& Stice, 1989), the 48- and 64cell stage in cattle (Bondioli et al., 1990) and the inner cell mass of the 120-cell blastocyst stage in sheep (Smith \& Wilmut, 1989).

The late blastocyst is a stage in mice at which embryonic stem cells can be removed, multiplied in culture, injected into another blastocyst to form chimaeras and used to produce germ cells and mice derived from the cultured stem cells (Evans \& Kaufman, 1981; Rossant \& Joyner, 1989). Several laboratories are attempting to isolate and culture embryonic stem cells from cattle, sheep and pigs (Evans et al., 1990).

This is being done in order to use stem cells as a means for gene transfer in which desired genes are introduced by transfection or by viral vector into the cultured stem cells which are then injected into blastocysts and used to make transgenic mice. These are stem cells and progenitors of all other cells. If they are identified in domestic animals, cultured to large numbers and totipotent as in mice, they will be useful as nuclear donor cells in nuclear transfer; this will allow clonal multiplication of embryos in the culture dish to numbers limited only by the multiplication rate of the cultured stem cells, perhaps resulting in as many as $10^{3}-10^{6}$ clones from one embryo. This has not yet been accomplished and the largest number of cloned domestic animals born so far has been 8 calves (Bondioli et al., 1990). 


\section{Use of nuclear transfer in livestock improvement}

Several important questions must be answered for a given species concerning variables contributing to success of nuclear transplantation. These variables will be addressed in the following review with primary focus on cattle and sheep. The procedural steps for nuclear transfer in cattle are shown in Fig. 1.

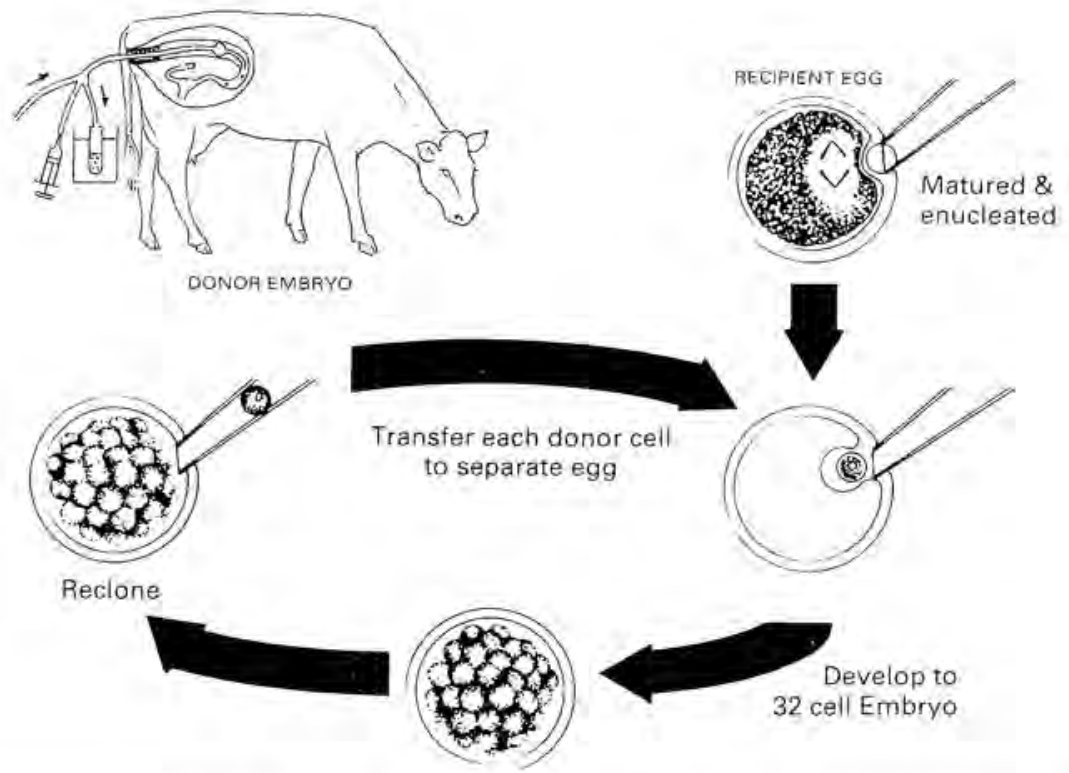

Fig. 1. Cloning bovine embryos by nuclear transfer. Morula- or blastocyst-stage embryos are flushed non-surgically from the uterus of a donor cow. The embryo cells (blastomeres without zona) are separated by aspiration and introduced by electrofusion into an enucleated secondary oocyte (with zona). The resulting embryo is cultured through preimplantation development to a multicellular stage of $\geq 30$ cells and the process repeated.

\section{The donor nuclei}

The latest stage from which development will occur after embryonic cells are used as nuclear donors in nuclear transfer is as yet unknown for domestic animals. Donor cells from the inner cell mass of the sheep blastocyst resulted in $56 \%$ development to the blastocyst stage (Smith \& Wilmut, 1989) and donor cells from cattle embryos recovered as late as Day 6 after hCG, a late morula stage averaging 48 cells and maximally 64, resulted in 35\% morulae or blastocysts (Bondioli et al., 1990; Marek et al., 1990). As shown in Table 1 developmental potential from Day 6 donor embryos of cattle was higher than from Day 5. The latest usable stage is still unknown and as yet the developmental fate of trophoblast cells versus inner cell mass has not been studied in ruminants. Evidence from mice and knowledge of the differentiation states of trophoblast cells indicate they should not result in development when used as nuclear donors (Illmensee \& Hoppe, 1981). The 64-cell and blastocyst stages used as nuclear donors in cattle and sheep are not far from the late blastocyst stage in mice and hamsters from which totipotent stem cells can be recovered from the epiblast and cultured to large numbers in vitro (Evans \& Kaufman, 1981; Doetschman et al,, 1988), If such stem 
cells can be identified and cultured in sheep and cattle (Evans et al., 1990; Notarianni et al., 1991) and if they are truly totipotent or become so after exposure to oocyte cytoplasm, then large numbers of clones $\left(10^{3}\right.$ or $10^{6}$ or more) can be produced from one valuable embryo.

Experiments in amphibians provide a basis for predicting the outcome of transferring nuclei from advanced-stage embryos. These experiments show that limited development occurs when nuclei beyond the blastula stage are used and that an irreversible differentiation occurs for an increasing population of cells as development progresses further and further past the blastula (Gurdon, 1964, 1986). Failure of development from differentiated nuclei can be assumed to result from the irreversible modification of embryonic chromatin (King, 1966; DiBerardino \& Hoffner, 1970).

It is also possible that failed development results from harvesting donor cells at an inappropriate stage of the cell cycle. The decreased rate of development observed from nuclei more advanced in development may not be entirely explained by differentiation alone. A major confounding factor is the change in the length of the cell cycle that occurs at the midblastula transition. Before the midblastula stage the length of the Xenopus cell cycle is about 35 min with no pause between $M$ and $S$ phases. This omission of $G_{1}$ and $G_{2}$ may explain the absence of transcription as RNA synthesis does not occur in $\mathrm{M}$ or $\mathrm{S}$ phases. As the embryo develops beyond the midblastula stage the cell cycle begins to lengthen progressively with the addition of both $G_{1}$ and $G_{2}$ phases while length of $M$ and $S$ phases remains unchanged, effectively lengthening the cell cycle as development proceeds. Nuclei that are transferred from cells that have long cell cycles would be required to divide earlier in their respective cell cycle after nuclear transfer as compared to nuclei from the blastula stage. Thus nuclei from more slowly dividing cells promote development at a higher rate if in $G_{2}$ when transferred (Von Beroldington, 1981), whereas the stage of the cell cycle may be less important for nuclei from rapidly dividing cells (McAvoy et al., 1975, Ellinger, 1978).

Although nuclei in $G_{1}$ undergo DNA synthesis after nuclear transfer to activated, enucleated metaphase II oocytes, in many instances the replication is not complete. This incomplete DNA replication results in chromosomal breakage and unequal inheritance among the daughter cells (Gurdon, 1964; DiBerardino \& Hoffner, 1970). Later in development the chromosomal abnormalities are manifest as developmental restriction points or stages that the nuclear transfer embryo is unable to progress beyond. That these restriction points are stably inherited is shown by retransfer, i.e. serial nuclear transfer (Briggs et al., 1964; DiBerardino \& King, 1965).

There are no studies in domestic species identifying the importance of or defining the stage of the cell cycle of blastomere donors most conducive to maximal development. In mice synchrony of stage of the cell cycle of donor and recipient cell was shown to be important for transfers between embryonic stages (Smith et al., 1988).

\section{Source of recipient cytoplasm}

The recipient cell stage appears to be critical for development after nuclear transfer. When donor cells are fused into enucleated 1-cell zygotes, development does not occur in mice (McGrath \& Solter, 1984; Robl et al., 1986; Tsunoda et al., 1987; Smith et al., 1988), rats (Kono et al., 1988) or cattle (Robl et al., 1987). In the mouse, when the recipient stage is the enucleated 2 -cell embryo and the donor cell is within one or two stages of the 2-cell (i.e. 4-8 cell) embryo, development and in one case birth have occurred (Robl et al., 1986; Tsunoda et al., 1987). With neither the zygote nor 2-cell recipient stage is there evidence of nuclear remodelling or swelling.

Success in cloning mammalian embryos came from adaptation of methods used in amphibians, namely use of the metaphase II-arrested oocyte as a recipient stage, with the hope that the oocyte would treat the introduced nucleus as it does a fertilizing spermatozoon. This method was first reported in mammals by Willadsen (1986) who showed that nuclei from sheep 8-cell blastomeres were able to support blastocyst development $(42-48 \%)$ and the birth of lambs. This is also the recipient stage that has resulted in transferable morulae and blastocysts as well as offspring in sheep 
(Willadsen, 1986; Smith \& Wilmut, 1989), cattle (Prather et al., 1987; Bondioli et al., 1990), rabbits (Stice \& Robl, 1989) and pigs (Prather et al., 1989a). Activated cytoplasm of secondary oocytes has the unique ability to promote nuclear envelope breakdown (Szollosi et al., 1988), chromatin condensation and decondensation (Newport \& Kirschner, 1984; Fisher, 1987), nuclear swelling (Gurdon, 1964; Prather et al., 1990) and translocation of cytoplasmic proteins into the nucleus and to some extent reprogramming of the genome (Merriam, 1969; DiBerardino \& Hoffner, 1975; Korn \& Gurdon, 1981; Prather et al., 1989b).

The stage of maturation of the oocyte at enucleation and nuclear transfer may be important. In amphibians fewer chromatin abnormalities and greater embryo development occur with introduction of the nucleus before metaphase II (Orr et al., 1986).

Most mammalian studies have attempted to use oocytes at metaphase II. In sheep (Smith \& Wilmut, 1989) and cattle, the optimum age for in-vivo matured oocytes has been reported to be $36 \mathrm{~h}$ after hCG or after oestrus (Prather et al., 1987; Bondioli et al., 1990). For cattle little difference was seen in one study for metaphase II oocytes collected $25-48 \mathrm{~h}$ after hCG (Bondioli et al., 1990), while $36 \mathrm{~h}$ after oestrus was superior to $48 \mathrm{~h}$ in another study (Prather et al., 1987). Studies pertaining to effects of time of insemination in relation to ovulation on pregnancy and embryo survival (Barrett, 1948; Casida, 1950) suggest that eggs 36 and $48 \mathrm{~h}$ after hCG or the beginning of oestrus should result in lower pregnancy and embryo survival. With the great lack of precision in estimating the physiological state of each cow at 24,36 and $48 \mathrm{~h}$, great overlap exists at all time points and time differences may not be distinguishable. Additionally, if oocyte activation and cell fusion are more efficient at later times as shown by Ware et al. (1989), this may bias the outcome in favour of the more aged egg. Oocytes matured in vitro require 18-24 h to reach metaphase II (Edwards, 1965; King et al., 1986; Suss et al., 1988; Sirard et al., 1989) and could be activated and fertilized by spermatozoa at that time (J. J. Parrish, personal communication). However, maximal artificial activation and hence suitability for nuclear transfer is not achieved until more than $30 \mathrm{~h}$ after removal from the ovarian follicle (Ware et al., 1989). This enigma needs resolution.

\section{Enucleation of the oocyte}

Removal of the oocyte metaphase chromatin and polar body appears essential for a high frequency of embryo development. This is best illustrated by the original experiment of Willadsen (1986) with sheep oocytes in which nuclei were transferred to enucleated and nucleated oocytes (Table 2). Enucleation has been performed by bisection of the oocyte, and rejection of the half with evidence of polar body or chromatin (Willadsen, 1986) or by aspiration of polar body and adjacent cytoplasm (Prather et al., 1987, 1989a; Stice \& Robl, 1989; Smith \& Wilmut, 1989). The efficiency of both methods can be greatly improved by staining the chromatin with a fluorescent chromatin dye such as DAPI or Hoechst 33258 (Critser \& First, I986; Tsunoda et al., 1988; Prather \& First, 1990a).

\section{Cell fusion}

Puncture of the oocyte plasma membrane by a needle of sufficient size to introduce a blastomere or nucleus is damaging to the oocyte (Illmensee \& Hoppe, 1981). Alternatively, a non-damaging introduction of blastomere or nuclei was accomplished originally in mice by use of Sendai virusinduced membrane fusion (McGrath \& Solter, 1983). In cattle this Sendai virus method or use of herpes virus gave little success (Robl et al., 1987). Electrofusion has been successful with ruminant eggs (sheep: Willadsen, 1986; cattle: Prather et al., 1987; Robl et al., 1987) and has become the method of choice when nuclear transfer has been successful in cattle, sheep, pigs and rabbits.

Earlier experiments indicated that the efficiency of cell fusion decreased rapidly as smaller and later stage donor blastomeres were used (cattle: Prather et al., 1987; sheep: Smith \& Wilmut, 1989). However, more recent reports show the opposite (Kinis et al., 1989), or only a small reduction in 
fusion efficiency with donor cells as late as the 40-64-cell stage (mean=48; Bondioli et al., 1990; Table 1). Efficient fusion depends on healthy cell membranes, physical contact of both oocyte and blastomere membranes to be fused, and direction of the fusion current primarily through the point of membrane contact (Zimmerman \& Vienken, 1982). Present methods allow fusion efficiencies of approximately $70 \%$ (Bondioli et al., 1990; Table 1).

Table 1. The effect of donor embryo age on the development of embryos produced by nuclear transfer (from Bondioli et al. (1990) and Marek et al. (1990))

\begin{tabular}{lcccccc}
\hline $\begin{array}{l}\text { Donor } \\
\text { embryo age } \\
\text { (days) }\end{array}$ & $\begin{array}{c}\text { Average } \\
\text { cell } \\
\text { no. }\end{array}$ & $\begin{array}{c}\text { No, of } \\
\text { attempted } \\
\text { fusions }\end{array}$ & $\begin{array}{c}\text { No. }(\%) \text { of } \\
\text { successful } \\
\text { fusions }\end{array}$ & $\begin{array}{c}\text { No, of } \\
\text { transferred } \\
\text { sheep }\end{array}$ & $\begin{array}{c}\text { No. }(\%) \text { of } \\
\text { recovered } \\
\text { sheep }\end{array}$ & $\begin{array}{c}\text { No. }(\%) \text { of } \\
\text { morulae and } \\
\text { blastocysts* }\end{array}$ \\
\hline $5 \cdot 0$ & $28 \cdot 2$ & 882 & $636(72)^{\mathrm{a}}$ & 882 & $842(95)$ & $196(23)^{3}$ \\
$5 \cdot 5$ & $30 \cdot 8$ & 212 & $149(70)^{\mathrm{a}}$ & 212 & $197(93)$ & $55(28)^{\mathrm{a} .65}$ \\
6.0 & $48 \cdot 3$ & 87 & $56(64)^{\mathrm{a}}$ & 87 & $84(97)$ & $29(35)^{\mathrm{b}}$ \\
\hline
\end{tabular}

* Compact morula or blastocyst after 6 days of culture in the ligated sheep oviduct.

*.b Different superscripts within the same column denote a significant difference $\left(\chi^{2}\right.$ analysis, $\left.P<0.05\right)$.

\section{Oocyte activation}

For completion of meiosis II and progress through subsequent stages of development, an oocyte must be activated. Oocytes are normally activated at fertilization by the fertilizing spermatozoon. For cattle this occurs optimally in vivo almost as soon as the oocytes reach the oviduct since the spermatozoa have been previously deposited in the reproductive tract and are already at the site of fertilization. However, in vitro only a few of the oocytes are capable of activation by electrofusion at $24 \mathrm{~h}$ after the start of culture and do not reach maximal activation until $\geq 30 \mathrm{~h}$ (Ware et al., 1989) and with a narrow window for successful later development.

Normally the electrostimulation used for cell fusion is sufficient to activate oocytes during nuclear transfer (Prather et al., 1987, 1989a; Robl \& Stice, 1989; Ware et al., 1989; Bondioli et al.. 1990; Smith \& Wilmut, 1990). These observations suggest that, because of late activation, oocytes used for nuclear transfer, whether recovered in vivo or in vitro, are relatively aged at the time of cell fusion. The window of opportunity for subsequent development may be very narrow. In mice, when thymocyte nuclei are fused into enucleated metaphase II oocytes, proper nuclear membrane breakdown and further reassembly occur only when cell fusion occurs immediately before or up to $30 \mathrm{~min}$ after oocyte activation (Czolowska et al,, 1984; Szollosi et al, 1988). A similar narrow window has been reported for sheep oocytes receiving nuclei from nuclear transfer of 32-to 64-cell stage blastomeres (Sun et al, 1989). Much more needs to be learned about the time of oocyte activation, nuclear transfer, the dedifferentiation of nuclei after transfer and subsequent embryonic development.

\section{Culture and development of the embryo resulting from nuclear transfer}

In nearly all cases the production of late stage embryos (morula or blastocyst) or pregnancies and calves after transfer have resulted from culture of the nuclear transfer embryos in agar blocks placed in the ligated oviducts of sheep (sheep: Willadsen, 1986; Smith \& Wilmut, 1989; cattle: Prather et al., 1987; Bondioli et al., 1990). In one reported study the frequency of embryo development to morula or blastocyst for nuclear transfer embryos cultured in vitro appeared to be approximately half $(13 \%)$ that obtained from culture of nuclear transfer embryos in sheep oviducts (23-35\%; Bondioli et al., 1990). This may reflect a sensitivity of embryos derived from nuclear transfer to in-vitro culture or an inadequacy of the in-vitro culture system. Embryos cultured in vitro by co-culture with oviduct 
epithelial cells or media conditioned by oviduct epithelial cells develop to morulae or blastocysts at nearly the same frequency as those cultured in sheep oviducts (Eyestone \& First, 1989) but the number of cells in the embryo is reduced by in-vitro culture after the 8-cell stage (Vergos et al., 1989; Barnes \& Eyestone, 1990) and development equivalent to the sheep oviduct occurs only for early cleaving in-vitro cultured embryos (Gordon \& Lu, 1990).

When bovine embryos derived from nuclear transfer are cultured in oviducts of sheep, the highest frequency of embryos reported to reach the morula to blastocyst stage is $23-35 \%$ of the oocyte-blastomere complexes which were subjected to fusion (Table 1; Bondioli et al., 1990). If $70 \%$ complete fusion, this represents $33-50 \%$ of the fusion products. In sheep maximal development has been $48 \%$ (Table 2; Willadsen, 1986) and 56\% (Smith \& Wilmut, 1989) of morulae or blastocysts.

Table 2. Cloning sheep embryos by blastomere transfer (from Willadsen, 1986)

\begin{tabular}{|c|c|c|c|c|c|}
\hline & & \multicolumn{4}{|c|}{ Recipient-metaphase oocyte } \\
\hline & & \multicolumn{2}{|c|}{ Enucleated } & \multicolumn{2}{|c|}{ Nucleated } \\
\hline & & $\begin{array}{l}\text { 8-cell } \\
\text { donor }\end{array}$ & $\begin{array}{l}\text { 16-cell } \\
\text { donor }\end{array}$ & $\begin{array}{l}\text { 8-cell } \\
\text { donor }\end{array}$ & $\begin{array}{l}\text { I6-cell } \\
\text { donor }\end{array}$ \\
\hline Embryos cultured & & 76 & 29 & 35 & 19 \\
\hline \multirow[t]{2}{*}{ Blastocysts developed } & No. & 32 & 14 & 4 & 1 \\
\hline & $\%$ & $42 *$ & 48 & 11 & 5 \\
\hline
\end{tabular}

* Of 4 transferred blastocysts, 3 resulted in blastomere donor type lambs (Willadsen, 1986).

\section{Pregnancies and pregnancy maintenance}

While offspring have been born from nuclear transfer in amphibians (Gurdon, 1986), mice (Illmensee \& Hoppe, 1981; Tsunoda et al., 1987), sheep (Willadsen, 1986; Smith \& Wilmut, 1989), cattle (Prather et al., 1987; Robl et al., 1987; Bondioli et al., 1990), pigs (Prather et al., 1989a) and rabbits (Stice \& Robl, 1989), the frequency of pregnancies and their survival have been lower than normal in all the above species. In cattle 42-day pregnancy rates after transfer of embryos formed by nuclear transfer to recipient cows were reported to average $22 \%$ and to be $33 \%$ for Grade I, $15 \%$ for Grade II and $11 \%$ for Grade III embryos (Bondioli et al., 1990). This is less than half the expected 50-60\% pregnancy rate from normal embryo transfer. Of 104 pregnancies at Day 42,92 resulted in live calves (Bondioli et al., 1990).

Why pregnancy rate and/or early pregnancy maintenance are reduced after nuclear transfer is unknown. In amphibians after nuclear transfer and especially with inappropriate timing, incomplete DNA replication occurs and results in chromosomal breakage and unequal inheritance among daughter cells (Gurdon, 1964; DiBerardino \& Hoffner, 1970), Later in development these chromosomal abnormalities are known to be manifest as developmental restriction points beyond which nuclear transfer embryos are unable to proceed. These restriction points are stably inherited as shown by serial retransfer of nuclei (Briggs et al., 1964; DiBerardino \& King, 1965). Further research is needed to improve pregnancy survival if nuclear transfer embryos are to be used for commercial embryo transfer.

Offspring resulting from nuclear transfer are not expected to be identical clones. Studies with bisected cattle embryos show differences in colour pigmentation probably due to differences in melanoblast migration patterns while embryos reside in different uterine environments (Seidel, 1985). The mitochondrial DNA and cytoplasmic environment will differ for each oocyte into which identical nuclei are transferred. We do not know the cytoplasmic or mitochondrial contribution to cattle traits but there is evidence for maternal influences on milk production in cattle (reviewed by 
Kirkpatrick \& Dentine, 1988). Additionally, any translocation (King \& Linares, 1983), diminution (Beerman, 1977), gene rearrangements (Alt et al., 1987), gene amplification (Tobler, 1975) or mutation in one or more cells of a donor embryo will be propagated and multiplied in descendant embryos by serial recloning.

To test identity of clones, numerous clones will need to be produced. At present the usual is $2-4$ and the maximum is one set of 8 (Bondioli et al., 1990). At the least it is expected that embryos resulting from nuclear transfer will be useful in genetic improvement because they will transmit through generations the benefits of non-additive as well as additive inheritance.

\section{Conclusions}

At present nuclear transfer has been accomplished in ruminants to produce multiple offspring from one donor embryo. Further research is needed to improve the efficiency of the procedure, its embryo multiplication potential, pregnancy rate and survival. Potentially, the procedure provides a mechanism for rapid genetic improvement and rapid propagation of a given genotype. It also provides the possibility for exciting research concerning the interaction of the nucleus, cytoplasm and environment in inheritance.

This research was supported by the College of Agricultural and Life Sciences, University of Wisconsin-Madison and a grant from W. R. Grace and Co.-Conn. We thank Dr Lorraine LeibfriedRutledge for assistance and advice on this manuscript and Julie Busby for typing and editing.

\section{References}

AIt, F.W., Blackwell, K. \& Yancopoulos, G.D. (1987) Development of the primary antibody repertoire. Science, NY 238, 1079-1087.

Barnes, F.L. (1988) Characterisation of the onset of embryonic control and early development in the borine embryo. Ph.D. thesis, University of WisconsinMadison.

Barnes, F.L. \& Eyestone, W.H. (1990) Early cleavage and the maternal zygotic transition in bovine embryos. Theriogenology 33, 141-152.

Barrett, G.R. (1948) Time of insemination and conception rates in dairy cows. $\mathrm{Ph} . \mathrm{D}$, thesis, University of Wisconsin-Madison.

Beerman, S. (1977) The diminution of heterochromatic chromosomal segments in Cyclops. Chromosoma 60 , 297-344.

Bondioli, K.R., Westhusin, M.E. \& Looney, C.R. (1990) Production of identical bovine offspring by nuclear transfer, Theriogenology 33, 165-174.

Briggs, R. \& King, T.J. (1952) Transplantation of living nuclei from blastula cells into enucleated frogs' eggs. Proc, nain. Acad. Sci, USA 38, 455-463.

Briggs, R., Signoret, J. \& Humphrey, R.R. (1964) Transplantation of nuclei of various cell types from neurulae of the Mexican axolotl (Ambystoma mexicannum). Dev/ Biol. 10, 233-246.

Casida, L.E. (1950) The repeat-breeder cow. Vlaams Diergen. Tijdschr. 19, 273-283.

Critser, E.S. \& First, N.L. (1986) Use of a fluorescent stain for visualization of nuclear material in living oocytes and early embryos. Stain Technol. 61, I-5.

Crosby, I.M., Gandolfi, F. \& Moor, R.M. (1988) Control of proteins synthesized during early cleavage of sheep embryos. J. Reprod. Feri. 82, 769-775.
Czolowska, R., Modlinski, J.A. \& Tarkowski, A.K. (1984) Behaviour of thymocyte nuclei in non-activated and activated mouse oocytes. J. Cell Sci. 69, 19-34.

DiBerardino, M.A. \& Hoffner, N.J. (1970) Origin of chromosomal abnormalities in nuclear transplantsa reevaluation of nuclear differentiation and nuclear equivalence in amphibians. Dev/ Biol . 23, 185-209.

DiBerardino, M.A. \& Hoffner, N.J. (1975) Nucleocytoplasmic exchange of nonhistone proteins in amphibian embryos. Exp/ Cell Res. 94, 235-252.

DiBerardino, M.A. \& King, T.J. (1965) Development and cellular differentiation of neural nucleartransplant embryos of known karyotype. Dev/ Biol. $15,102-128$.

Doetschman, T., Williams, P. \& Maeda, N. (I988) Establishment of hamster blastocyst-derived embryonic stem (ES) cells. Devl Biol, 127, 224-227.

Edwards, R.G. (1965) Maturation in virre of mouse, sheep, cow pig, rhesus monkey and human ovarian oocytes. Nature, Land. 208, 349-351.

Ellinger, M.S. (1978) The cell cycle and transplantation of blastula nuclei in Bombiana orientalis. Dev/ Biol. $65,81-89$.

Evans, M.J. \& Kaufman, M.H. (1981) Establishment in culture of pluripotential cells from mouse embryos. Nature. Lond. 294, 154-156.

Evans, M.J., Notarianni, E., Laurie, S. \& Moor, R.M. (I990) Derivation and preliminary characterization of pluripotent cell lines from porcine and bovine blastocysts. Theriogenology 33, 125-128.

Eyestone, W.H. \& First, N.L. (1989) Co-culture of early bovine embryos to the blastocyst stage with oviducal tissue or in conditioned medium. J. Reprod. Fert. 85, $715-720$. 
Fischberg, M., Gurdon, J.B. \& Elsdale, T.R. (1958) Nuclear transplantation in Xenopus laevis. Nature, Lond. 181, 424.

Fisher, P.A. (1987) Disassembly and reassembly of nuclei in cell free systems. Cell 48, 175-176.

Flach, G., Johnson, M.H., Braude, P.R., Taylor, R.A.S. \& Bolton, V.N. (1982) The transition from maternal to embryonic control in the 2-cell mouse embryo. EMBO J, 6, 681-686.

Gordon, I. \& Lu, K.H. (1990) Production of embryos in vitro and its impact on livestock production. Theriogenology 33, 77-88.

Gurdon, J.B. (1964) The transplantation of living cell nuclei. Adv. Morphol. 4, 1.

Gurdon, J.B. (1986) Nuclear transplantation in eggs and oocytes. J. Cell Sci. 4 (Suppl), 287-318.

Illmensee, K. \& Hoppe, P.C. (1981) Nuclear transplantation in Mus musculus: developmental potential of nuclei from preimplantation embryos. Cell 23, 9-18.

King, T.J. (I966) Nuclear transplantation in amphibia. Methods in Cell Biol. 2, 1-35.

King, W.A. \& Linares, T. (1983) A cytogenetic study of repeat-breeder heifers and their embryos. Can. vet. $J$. 24, $112-117$.

King, W.A., Bousquet, D., Greve, T. \& Goff, A.K. (1986) Meiosis in bovine oocytes matured in vitro and in vivo. Acta vet. scand. 27, 267-279

Kinis, A., Vergos, E., Gallagher, M. \& Gordon, A. (1989) Studies in nuclear transplantation using bovine oocytes and embryos produced by in vitro culture techniques, $J$. Reprod. Fert., Abstr. Ser. 4, p. 22.

Kirkpatrick, B.W. \& Dentine, M.R. (1988) An alternative model for additive and cytoplasmic genetic and maternal effects on lactation. J. Dairy Sci. 71, 2502-2507.

Kono, T., Shioda, Y. \& Tsunoda, Y. (1988) Nuclear transplantation of rat embryos. J.exp. Zool. 248, 303-305.

Korn, L.J. \& Gurdon, J.B. (1981) The reactivation of developmentally inert $5 \mathrm{~S}$ genes in somatic nuclei injected into Xenopus oocytes. Nature, Lond. 289, $461-465$.

Marek, D.E., Pryor, J.H., Whitesell, T.H. \& Looney, C.R. (1990) Nuclear transplantation in the bovine: effect of donor embryo age on subsequent embryo production. Theriogenology 33, 283, abstr.

MeAvoy, J.W., Dixon, K.E. \& Marshall, J.A. (1975) Effects of differences in mitotic activity, stage of the cell cycle and degree of specialization of donor cells on nuclear transplantation in Xenopus laevis: Des] Biol. 45, 330-339.

McGrath, J. \& Solter, D. (1983) Nuclear transplantation in the mouse embryo by microsurgery and cell fusion. Science, NY 220, 1300-1302.

McGrath J. \& Solter, D. (1984) Inability of mouse blastomere nuclei transferred to enucleated zygotes to support development in vitro. Science, $N Y 226$, 1317-1319.

McKinnell, R.G. (1962) Intraspecific nuclear transplantation in frogs. I. Hered. 53, 199-207.

Merriam, R.W. (1969) Movement of cytoplasmic proteins into nuclei induced to enlarge and initiate DNA or RNA synthesis. J. Cell Sci. 5, 333-349.

Nakakura, N., Miura, T.. Yamaua, K.. Ito, A.\& Shiokawa, K. (1987) Synthesis of heterogeneous mRNA-like RNA and low-molecular-weight RNA before the midblastula transition in embryos of Xenopus laevis. Devl Biol. 123, $421-429$.

Newport, J.W. \& Kirschner, M.W. (1984) Regulation of the cell cycle during early Xenopus development. Cell 37, 731-742.

Notarianni, E., Galli, C., Laurie, S., Moor, R.M. \& Evans, M.J. (1991) Derivation of pluripotent, embryonic cell lines from the pig and sheep. J. Reprod. Ferl.,Suppl.43, 255-260.

Orr, N.H., DiBerardino, M.A. \& McKinnell, R.G. (1986) The genone of the frog displays centuplicate replications. Proc. natn. Acad. Sci. USA 83, 1369-1373.

Prather, R.S. \& First, N.L. (1990a) Cloning of embryos. $J$. Reprod. Fert., Suppl. 40, 227-234.

Prather, R.S. \& First, N.L. (1990b) Nuclear transfer, In In Vitro Fertilization and Alternate Assisted Reproduction (in press).

Prather, R.S., Barnes, F.L., Sims, M.M., Robl, J.M. Eyestone, W.H. \& First, N.L. (1987) Nuclear transfer in the bovine embryo: assessment of donor nuclei and recipient oocyte. Biol. Reprod. 37, 859-866.

Prather, R.S., Sims, M.M. \& First, N.L. (1989a) Nuclear transplantation in early pig embryos. Biol. Reprod. 41, 414-481.

Prather, R.S., Sims, M.M., Maul, G.G., First, N.L. \& Schatten, G. (1989b) Nuclear lamin antigens are developmentally regulated during porcine and bovine embryogenesis, Biol, Reprod. 41, 123-132.

Prather, R.S., Sims, M.M. \& First, N.L. (1990) Nuclear transplantation in the pig embryo: nuclear swelling. J. exp. Zool. 255, 355-358.

Robl, J.M. \& Stice, S.L. (1989) Prospects for the commercial cloning of animals by nuclear transplantation. Theriogenology 31, 75-84.

Robl, J.M., Gilligan, B., Critser, E.S. \& First, N.L. (1986) Nuclear transplantation in mouse embryos: assessment of recipient cell stage. Biol. Reprod. 34, 733- 739 .

Robl, J.M., Prather, R., Barnes, F., Eyestone, W., Northey, D., Gilligan, B. \& First, N.L. (1987) Nuclear transplantation in bovine embryos. J. Anim. Sci. 64, 642-647.

Rossant, J. \& Joyner, A.L. (1989) Towards a moleculargenetic analysis of mammalian development. Trends in Genetics 5, 227-282.

Seidel, G.E., Jr (1985) Are identical twins produced from micromanipulation always identical? Proc. Ann. Conf. A.I. and Embryo Transfer in Beef Cattle (Denver), pp 50-53. Natl. Assoc Anim. Breeders. Columbia.

Sirard, M.A., Florman, H.M., Leibfried-Rutledge, M.L., Barnes, F.L., Sims, M.L. \& First, N.L. (1989) Timing of nuclear progression and protein synthesis necessary for meiotic maturation of bovine oocytes. Biol. Reprod 40, 1257-1263.

Smith, L.C. \& Wilmut, I. (1989) Influence of nuclear and cytoplasmic activity on the development in vivo of sheep embryos after nuclear transplantation. Biol. Reprod 40, 1027-1035.

Smith, L.C. \& Wilmut, I. (1990) Factors affecting the viability of nuclear transplanted embryos. Theriagenology 33, I53-164.

Smith, L.C., Wilmut, I. \& Hunter, R.H.F. (1988) Influence of cell cycle stage at nuclear transplantation on the development in vitro of mouse embryos. J. Reprod. Fert. 84, 619-624. 
Stice, S.L. \& Robl, J.M. (1989) Nuclear reprogramming in nuclear transplant rabbit embryos. Biol. Reprod. 39, 657-664.

Sun, F.S., Laurie, M.S. \& Moor, R.M. (1989) Nuclearcytoplasmic interactions in ovine reconstituted embryos. J. Reprod. Fert., Abstr. Ser. 4, 15.

Suss, I., Wuthrick, K. \& Stranzinger, G. (1988) Chromosome configurations and the sequence of the first meiotic division in bovine oocytes matured in vitro. Biol. Reprod. 38, 871-880.

Szollosi, D., Czolowska, R., Szollosi, M.S. \& Tarkowski, A.K. (1988) Remodeling of mouse thymocyte nuclei depends on the time of their transfer into activated homologous oocytes. J. Cell Sci. 91, 603-613.

Tobler, H. (1975) The occurrence and developmental significance of gene amplification. In Biochemistry of Animal Development, vol. 3, pp. 91-123. Ed. R. Weber. Academic Press, New York.

Tomanek, M., Kopecny, V. \& Kanka, J. (1989) Genome reactivation in developing early pig embryos: an ultrastructural analysis. Anat. Embryol. 180, 309-316.
Tsunoda, Y., Yasui, T., Shioda, Y., Nakamura, K., Uchida, T. \& Sugie, T. (1987) Full term development of mouse blastomere nuclei transplanted into enucleated twocell embryos. J. exp. Zool. 242, 147-151.

Tsunoda, Y., Shioda, Y., Onodera, M., Nakamura, K. \& Uchida, T. (1988) Diflerential sensitivity of mouse pronuclei and zygote cytoplasm to Hoechst staining and ultraviolet irradiation. $J$, Reprod. Fert, 82, 173-178,

Vergos, E., Gordon, A., Gallagher, M. \& Gordon, I. ( 1989 ) In vitro culture of embryos produced by in vitro maturation and IVF of bovine oocytes, Anim. Prod. 48, 621, abstr.

Von Beroldington, C.H. (1981) The developmental potential of synchronized amphibian cell nuclei. Devl Biol. 81, 115-126.

Ware, C.B., Barnes, F.L., Maiki-Laurila, M. \& First, N.L. (1989) Age dependence of bovine oocyte activation. Gumete Res. 22, 265-275.

Willadsen, S.M. (1986) Nuclear transplantation in sheep embryos. Nature, Lond. 320, 63-65.

Zimmerman,U.\& Vienken, J. (1982) Electric field-induced cell-to-cell fusion. $J$. Memhrane Biol. 67, 165-182. 